\title{
Table of legal instruments
}

\section{INTERNATIONAL}

Aarhus Convention on Access to Information, Public Participation in Decision-Making and Access to Justice in Environmental Matters (adopted 25 June 1998, entered into force 30 October 2001) 2161 UNTS 447 (Aarhus Convention) 92, 136, 140, 144, 175, 198, 199, 200, 203-7, 208, 209, 210, 211, 212 , $213,214,266,343,348$

Preamble

Art 1

Art 2

Art 3

Art 4

Art 5

Art 6

Arts 7, 8

Art 9

Art 15 African Charter on Human and Peoples' Rights
(adopted 27 June 1981, entered into force 21 October 1986) 1520 UNTS 217 Art 24

African-Eurasian Migratory Waterbird Agreement (adopted 16 June 1995, entered into force 1 November 1999) 2365 UNTS 203

205, 208, 210

136

138

203, 209

203

137, 138, 203

203

03, 204

199, 204

greement on Subsidies and Countervailing Measures (adopted 15 April 1994, entered into force 1 January 1995) 1869 UNTS 14 (SCM Agreement)

364,365

\section{Art 3}

Art 8

Agreement on Technical Barriers to Trade (adopted 15 April 1994, entered into force 1 January 1995) 1868 UNTS 120 (TBT Agreement)

$85,273,352,356$

Art 2

Agreement on Trade-Related Aspects of 85,273 Intellectual Property Rights (adopted 15 April 1994, entered into force 1 January 1995) 1869 UNTS 299 (TRIPS)

352,360
American Convention on Human Rights (adopted 22 November 1969, entered into force 18 July 1978) 1144 UNTS 123

342,347

Additional Protocol to the American Convention on Human Rights in the Area of Economic, Cultural and Social Rights (adopted 17 November 1988, entered into force 16 November 1999) 28 ILM 1561

Bern Convention on the Conservation of European Wildlife and Natural Habitats (adopted 19 September 1979, entered into force 1 June 1982) 1284 UNTS 210

Cartagena Protocol on Biosafety to the Convention on Biological Diversity (adopted 29 January 2000, entered into force 11 September 2003) 2226 UNTS 208

Convention Concerning the Protection of the World Cultural and Natural Heritage (adopted 16 November 1972, entered into force 17 December 1975) 1037 UNTS 151

Art 2

Convention on Biological Diversity (adopted 22 May 1992, entered into force 29 December 1993) 31 ILM 818

$55,171,185,187$, $190,192,195,197,222,250$

Art 8

Art 9

Convention on the Conservation of Migratory Species of Wild Animals (adopted 23 June 1979, entered into force 1 November 1983) 19 ILM 15 171,182

Convention on International Trade in Endangered Species of Wild Fauna and Flora (adopted 3 March 1973, entered into force 1 July 1975) 993 UNTS 243

Preamble 250

Convention on Long-Range Transboundary Air Pollution (adopted 16 November 1979, entered into force 16 March 1983) 1302 UNTS 217 (LRTAP) 20, 22, 23, 24

Convention for the Protection of the Marine Environment of the North-East Atlantic (adopted 22 September 1992, entered into force 25 March 1998) (OSPAR) 2354 UNTS 67 
Convention on the Settlement of Investment Disputes Between States and Nationals of Other States (International Centre for Settlement of Investment Disputes [ICSID]) (adopted 18 March 1965, entered into force 14 October 1966) 575 UNTS 159

Convention on Wetlands of International Importance Especially as Waterfowl Habitat (adopted 2 February 1971, entered into force 21 December 1975) 11 ILM 963 (Ramsar Convention)

171, 191, 195, 196

European Convention for the Protection of Human Rights and Fundamental Freedoms (4 November 1950, entered into force 3 September 1953) 213 UNTS $221 \quad \mathbf{1 7 4 , 3 4 2 ,}$ 348, 349

Art 2 347

Art 8 175,347

General Agreement on Tariffs and Trade 1994 (adopted 15 April 1994, entered into force 1 January 1995), 1867 UNTS 187 (GATT)

Art I

$85,352,353$

Art III

Art XI

Art XX 273, 275, 276, 353, 355, 356, 359 274, 275 275, 276, 280, 352, 354, 355,

Gothenburg Protocol to Abate Acidification, 356, 362, 363, 364, 365

Eutrophication and Ground-Level Ozone to the Convention on Long-range Transboundary Air Pollution (adopted 30 November 1999, entered into force 15 May 2005) 2319 UNTS 81

International Covenants on Civil and Political

Rights and on Economic, Social and Cultural Rights (adopted 16 December 1966, entered into force 3 January 1976) 993 UNTS 3

Joint Protocol Relating to the Application of the Vienna Convention and the Paris Convention (adopted 21 September 1988, entered into force 27 April 1992) 1672 UNTS 302

Kyoto Protocol to the United Nations Framework Convention on Climate Change (adopted 11 December 1997, entered into force 16 February 2005) 2303 UNTS 162

24, 116, $118,119,174,183,184,216,255,287,288$, 290, 291

Art 3

Art 6

Art 9

Art 12

Art 17

Art 26
24,288

289 288

184,289 289 287
Art 20

Art 27

Annex B 24

London Convention on the Prevention of Marine Pollution by Dumping of Wastes and Other Matter (29 December 1972, entered into force 30 August 1975) 11 ILM 1294

Minamata Convention on Mercury (adopted 10 October 2013, entered into force 16 August 2017) 55 ILM 582

Nagoya Protocol on Access to Genetic Resources and the Fair and Equitable Sharing of Benefits Arising from their Utilization to the Convention on Biological Diversity (adopted 29 October 2010, entered into force 12 October 2014) UNEP/CBD/COP/DEC/X/1

Paris Agreement under the United Nations Framework Convention on Climate Change (adopted 12 December 2015, entered into force 4 November 2016) 55 ILM $740 \mathbf{2 0 , 2 2 ,}$ 24-5, 28, 29, 31, 44, 74, 105, 116, 117, 118, $119,120,124,174,180,181,183,184,195$, 217, 224, 233, 246, 248, 287, 288, 314, 357,

Preamble 358, 371

Art 2 217

Art 3

Art 4

Art 5

Art 6

24, 217

184,288

$24,117,118,217,233,288,365,366$

185, 186, 295

184, 186, 293

Art 7 117

Art 11 117,252

Art 12

118,252

Art 13

Art 14

Art 15

Art 16

$118,119,217,288$

29, 119, 217, 288

118, 217

Art 22

116

Art 27

Art 28

287

Protocol on Environmental Protection to the Antarctic Treaty (adopted 4 October 1991, entered into force 14 January 1998) 2941 UNTS 5778

Regional Agreement on Access to Information, Public Participation and Justice in Environmental Matters in Latin America and the Caribbean (adopted 4 March 2018, not yet in force) LC/CNP10.9/5 (Escazú Agreement) 199, 200, 206, 207, 209, 210,

Art 3 211, 213, 214, 344

Art 4

208, 210, 213

Art 5

209, 213

Art 6 
Arts 7,8

Art 9

Rio Declaration on Environment and

Development (adopted 13 June 1992) 31

ILM 874

Principle 10

$198,345,350$

Principle 15

198-200, 202, 205, 206, 210 , $211,213,214,343,344$

Statute of the International Court of Justice (adopted 26 June 1945, entered into force 24 October 1945) 39 AJIL Supp. 215

Art 38

Stockholm Declaration of the United Nations Conference on the Human Environment (adopted 16 June 1972) UN Doc. A/ CONF.48/14/REV.12 39, 202, 281, 342, $343,345,373$

United Nations Convention to Combat

Desertification in Those Countries

Experiencing Serious Drought and/or

Desertification, Particularly in Africa

(adopted 14 October 1994, entered into force 26 December 1996) 1954 UNTS 3 (UNCCD)

190, 196, 222

United Nations Framework Convention on Climate Change (adopted 9 May 1992, entered into force 21 March 1994) 1771 UNTS 107 (UNFCCC) 22, 24, 29, 92, 105, $116,155,174,183,184,185,190,195,197$, 216, 220, 238, 252, 287, 289, 292, 293, 294,

Art 4

366,371

Art 6

24,92

Arts 24, 25

252, 293

Universal Declaration of Human Rights (10 December 1948) A/RES/3/217 A

Vienna Convention for the Protection of the Ozone Layer (adopted 22 March 1985, entered into force 22 September 1988) 26 ILM 1529

Vienna Convention on the Law of Treaties (adopted 23 May 1969, entered into force 27 January 1980) 1155 UNTS 331

\section{EUROPEAN UNION}

Charter of Fundamental Rights of the European Union, 2000

Art 37

Directive 85/337/EEC on the assessment of the effects of certain public and private projects on the environment [1985] OJ L $175 / 40$
Directive 92/43/EEC on the conservation of natural habitats and of wild fauna and flora [1992] OJ L 206/7

$181,183,191,193$

Art 16

Art 22

Directive 1999/31/EC on the landfill of waste [1999] OJ L 182/1

Directive 2000/60/EC establishing a framework for Community action in the field of water policy [2000] OJ L 327/1

Directive 2006/12/EC on waste [2006] OJ L $114 / 9$

Directive 2007/60/EC on the assessment and management of flood risks [2006] OJ L $288 / 27$

Directive 2008/50/EC on ambient air quality and cleaner air for Europe [2008] OJ L 152/1

Arts 15,16

Directive 2008/56/EC establishing a framework for community action in the field of marine environmental policy (Marine Strategy Framework Directive) [2008] OJ L $164 / 19$

Directive 2008/101/EC amending Directive 2003/87/EC so as to include aviation activities in the scheme for greenhouse gas emission allowance trading within the Community [2008] OJ L 8/3

Directive 2009/28/EC on the promotion of the use of energy from renewable sources and amending and subsequently repealing Directives 2001/77/EC and 2003/30/EC [2009] OJ L140/16 Art 29

Directive 2009/147/EC on the conservation of wild birds [2009] OJ L 20/7

$181,183,191$

Directive 2010/75/EU on industrial emissions (integrated pollution prevention and control) [2010] OJ L 334/17

341

Directive 2011/65/EU concerning the restriction of the use of certain hazardous substances in electrical and electronic equipment [2011] OJ L 174/88

Directive 2014/95/EU amending Directive 2013/34/EU as regards disclosure of non-financial and diversity information by certain large undertakings and groups [2014] OJ L330/1

Directive (EU) 2016/2284 on the reduction of national emissions of certain atmospheric pollutants, amending Directive 2003/35/EC and repealing Directive 2001/81/EC [2016] OJ L 344/1

Annex II 
Regulation (EEC) 2092/91 on organic production of agricultural products and indications referring thereto on agricultural products and foodstuffs [1991] OJ L 198/1 73

Regulation (EU) No. 421/2014 amending Directive 2003/87/EC establishing a scheme for greenhouse gas emission allowance trading within the Community, in view of the implementation by 2020 of an international agreement applying a single global market-based measure to international aviation emissions [2014] OJ L129/1

Regulation 443/2009 of the European Parliament and of the Council of 23 April 2009 setting emission performance standards for new passenger cars as part of the Community's integrated approach to reduce $\mathrm{CO} 2$ emissions from light-duty vehicles [2009] OJ L 140/1

Regulation (EC) No. 1221/2009 on the voluntary participation by organisations in a Community eco-management and audit scheme (EMAS), repealing Regulation (EC) No. 761/2001 and Commission Decisions 2001/681/EC and 2006/193/EC [2009] OJ L $342 / 1$

Regulation 995/2010/EU laying down the obligations of operators who place timber and timber products on the market [2010] OJ L 295/23

187

Regulation (EU) No. 1305/2013 on support for rural development by the European Agricultural Fund for Rural Development (EAFRD) and repealing Council Regulation (EC) No. 1698/2005 [2013] OJ L 347/487 Art 5

Regulation 1143/2014/EU on the prevention and management of the introduction and spread of invasive alien species (IAS Regulation) [2014] OJ L 317/35

Arts 2, 4

Regulation 2018/841/EU on the inclusion of greenhouse gas emissions and removals from land use, land use change and forestry in the 2030 climate and energy framework [2018] OJ L 156/1

186, 189

Treaty of Accession of the Czech Republic, Estonia, Cyprus, Latvia, Lithuania, Hungary, Malta, Poland, Slovenia and Slovakia [2003] OJ L 236/17

Treaty of Accession of the Republic of Bulgaria and Romania [2005] OJ L157/11

Treaty of Accession of Croatia [2012] OJ L $112 / 21$

113
Treaty of the European Community (TEC) Art 174

Treaty on the Functioning of the European Union (TFEU)

Art 34

Art 101

Art 102

Art 106

$130,132,133$

Art 191

130, 131, 133

Arts 258, 260

131,134

347

Art 263

$111,114,115$

140

\section{NATIONAL}

\section{Germany}

Basic Law for the Federal Republic, 1949

161

Art 20a

162

\section{Laos}

Constitution, 1991

Art 19

162

\section{Myanmar}

Constitution, 2008

Art 390b

162

\section{New Zealand}

Resource Management Act, 1991

250

\section{Republic of Ecuador}

Environmental Management Act, 1999

\section{Republic of South Africa}

Constitution, 1996

s 24

163,176

s 39

176

National Environmental Management Act 107 of 1998

163

\section{Thailand}

Constitution, 1997
Ch XIV

162 
xxiv Research handbook on transnational environmental law

\section{United Kingdom}

Countryside and Rights of Way Act, 2000

\section{United States of America}

28 U.S. Code $\S 1782$

Alien Tort Statute 28 U.S.C. 1350 (US) $\mathbf{3 2 0 ,} \mathbf{3 3 6}$

Clean Air Act, 1963

$44,311,356$

European Union Emissions Trading Scheme Prohibition Act, 2011, H.R. 2494

272

National Environmental Policy Act, $1972 \quad 344$

Racketeer Influenced and Corrupt Organizations

(RICO) Act, 1970

318, 326

250
Recognition of Foreign Country Money Judgments Act, 1962

$323,327,328,329,338$

U.S. Code $\S 4321$

Wild and Scenic Rivers Act, 1968

Yugoslavia

Constitution, 1974

161

\section{Zimbabwe}

Constitution, 2013

s 73

176 